\title{
ENRICHING THE LEGAL ETHICS CURRICULUM: FROM REQUIREMENT TO DESIRE
}

\author{
HEIDI LI FELDMAN*
}

\section{INTRODUCTION}

The problem has become all too familiar: Acting at least in part from noble motives, the American Bar Association ("ABA") requires all law students at ABA-accredited law schools to take a course in "professional responsibility." Every accredited school offers a course or courses that enable students to fulfill this requirement. Under these circumstances, the professional responsibility course can easily assume the character of high school drivers' education or health classes: It often becomes an obligatory exercise, in which students think they must woodenly learn the maxims of the ABA Code of Conduct or Rules of Professional Responsibility. Faced with this attitude from students, even the most dedicated, creative teacher sometimes falls into mechanistic pedagogy, teaching what the students apparently expect, in the shadow of the bureaucratic tone set by the ABA's influence on the curriculum.

At the University of Michigan Law School, the faculty has been trying-with generous assistance from the W.M. Keck Foundation-to correct this problem. Our efforts fall into three general categories: increasing students' awareness of the practical significance of legal ethics and the relationship between legal ethics and other areas of law; advancing students' appreciation of the complexity of the subject by enriching the philosophical, sociological, historical, and practical dimensions of our legal ethics courses; and inspiring faculty scholarship related to legal ethics, which will, in turn, be brought to bear on teaching students legal ethics.

Talk is cheap. When speaking in broad terms, it is relatively easy to express our aspirations for the legal ethics curriculum. The faculty has also begun the more demanding process of implementing and achieving these goals. The exciting results already achieved have prompted the faculty and dean to set the institution's sights even higher. In this essay, I will describe some of Michigan's innovations in the area of professional responsibility and outline some of our plans to expand and improve the reforms already in place. Many faculty

\footnotetext{
Copyright $(\mathcal{C} 1996$ by Law and Contemporary Problems

* Assistant Professor of Law, University of Michigan.

Thanks to Lucy Clark for research assistance and to David Wilkins and Kent Syverud for helpful comments.
} 
members other than myself have contributed to our ongoing transformation of the legal ethics program. I will try to do justice to these colleagues in this essay, noting their initiatives and views whenever possible. I will probably fail, however, leaving my authorial and pedagogical fingerprints all over others' ideas and contributions. I apologize for that in advance.

Three individuals must be specifically acknowledged for their contributions to Michigan's efforts to revitalize the legal ethics curriculum: Professor Carl Schneider; ${ }^{1}$ Professor Kent Syverud; ${ }^{2}$ and Dean Jeffrey Lehman. ${ }^{3}$ Each of them has also been closely involved with the Keck Foundation's contribution to Michigan's efforts.

\section{THE CURRICULUM IN Legal ETHICS}

Michigan's curricular innovations take two main forms. First, we have introduced a one-week intensive mini-course on legal ethics, which has been taught to the entire first-year class in the 1995-96 academic year. This innovation builds on an existing program of punctuating the traditional first-year classes with "bridge weeks," one-week intensive mini-courses on specific topics. Second, for the past several years, we have offered annually at least one upperlevel seminar on some topic(s) in applied legal ethics. While we still offer the traditional professional responsibility course, we anticipate modifying this course once it is taught by faculty members who have developed the legal ethics bridge weeks and the upperlevel seminars and is taken by students who have all experienced the legal ethics week in their first year. In this way, we will maintain some degree of continuity with the older professional responsibility curriculum while modifying it to eliminate those familiar problems I mentioned at the outset of this essay.

Before the Keck Foundation supplied us with the resources to create our current, ambitious legal ethics bridge weeks, some of Michigan's faculty had already experimented with a bridge week focused on legal ethics. This topic was a natural choice because in every bridge week, regardless of topic, faculty members attempt to show connections between the traditional first-year subjects, introduce ideas and materials from other disciplines into the study of law, and have students relate what they are learning to situations drawn from the cutting edge of legal practice. With the aid of the Keck Foundation, the faculty has been able to develop a highly robust ethics bridge week: We have created a set of course materials, used each year (with modification as necessary); we consistently arrange for an outstanding visiting legal ethics scholar to collaborate with Michigan faculty in conducting the week; and we invite a wide range of outside speakers to address the class.

1. Professor, University of Michigan Law School.

2. Associate Dean of Faculty, University of Michigan Law School.

3. Dean, University of Michigan Law School. 
By having a first-year ethics bridge week taught by visiting and internal experts who use an exciting variety of teaching materials, we aim to preempt the drivers' education mentality toward legal ethics. Teaching the legal ethics bridge week in the first year conveys to students that the study of ethics is as significant as the other, more traditional first-year subjects. Law students tend to assign great-perhaps exaggerated-importance to first-year offerings. We capitalize on this tendency not only by situating the bridge week in the first year, but by suspending the other first-year courses for the duration of the week.

Were it not for the drivers' education problem, a less imaginative, less resourceful first-year bridge week or lecture series might convey the tremendous importance of legal ethics. But because we have to overcome the historic marginalization of the subject, adding a dose of focus and dynamism to ethics instruction in the first year is essential.

One might urge that the ideal way to combat the drivers' education attitude would be to require first-years to take a full-blown course in legal ethics. We have chosen not to do this because we believe first-year students have not had sufficiently extensive exposure to various areas of law and legal practice to take full advantage of such a course. In their second and third years, law students are not as distracted by skills training, have taken more public law and constitutional law courses, and have usually had some legal work experience. Each of these traits positions upperclass law students to digest better a full course in legal ethics. More advanced students can better assimilate the entire range of materials systematically used in a strong legal ethics course, can more clearly comprehend the ways in which problems in legal ethics arise in different practice situations, and can understand more completely why solutions to these problems may vary according to professional context.

Ideally, then, the first-year bridge week should whet law students' appetites for more extensive and careful study of legal ethics in the second and third years of their education. The faculty does not intend the bridge weeks to complete the students' exposure to legal ethics but instead to stimulate students' desire to study the subject more thoroughly. We have some evidence that the bridge weeks have indeed had this effect. Although staffing shortages have forced us to allow students to count bridge week attendance as fulfilling the professional responsibility requirement (a practice we plan to discontinue as soon as possible), a significant number of students who have participated in ethics bridge weeks voluntarily enroll in upperlevel legal ethics courses and seminars. Of the ninety-three students who participated in the Keck-funded ethics bridge week, twenty took one additional upperlevel offering in legal ethics, and one student took two. Fourteen of these students attended one of the two traditional professional responsibility courses we offer. Of the eightyseven first-year participants in the second Keck-funded ethics week, nineteen took an upperlevel legal ethics course. Twelve enrolled in one of the traditional courses. This early data suggests that the enhanced ethics bridge weeks may 
indeed inspire student interest in legal ethics. As we improve and develop the upperlevel legal ethics curriculum, we expect to see increasing numbers of students voluntarily follow-up the first-year bridge weeks with more comprehensive study in legal ethics.

\section{III}

\section{MICHIGAN's FIRST KECK-FUNDED BRIDGE WEEK}

The following rather detailed description of the first bridge week designed by Michigan faculty using funds from its Keck grant will illustrate the workings of a bridge week in legal ethics for first-year law students. This week has become the basis for subsequent legal ethics bridge weeks, including the program in which all first-year students participated during the 1995-96 school year.

Because of the tremendous amount of faculty effort required to compile any bridge week, one or two faculty members take primary responsibility for organization. In 1993-94, I agreed to oversee the legal ethics week. Although I had not previously investigated legal ethics, my own interest in the area stemmed in part from my doctoral work in philosophy, in which I specialized in ethics and political philosophy. Michigan's Keck grant gave us the chance to hire an "outside expert" in the area of legal ethics: an accomplished senior faculty member from another institution whose primary teaching and research interests lay in legal ethics. This expert would assume much of the responsibility for the week's curricular content and structure, while I would provide assistance in these areas and handle much of the logistical work. Because I was a relatively young scholar and untenured at the time (I joined Michigan's faculty in the fall of 1991), this partnership arrangement made especially good sense.

We were lucky enough to entice Professor David Luban ${ }^{4}$ to be the outside expert for our first Keck-aided legal ethics bridge week. The students benefitted enormously from Professor Luban's tremendous knowledge and experience and from his superb teaching. I, too, learned from Professor Luban, who invited me to collaborate with him on all aspects of the week. Professor Luban also generously assumed a portion of the administrative responsibility.

At the outset, Professor Luban and I agreed that the course materials should be multimedia, including videotapes of documentaries on lawyers' ethics that Professor Luban had used before with great success. We also took advantage of our fiscal resources by inviting a wide range of guest speakers drawn from the ranks of legal practice and the legal academy, as well as educated observers of the current state of the legal profession such as Lincoln Caplan, a well-known writer specializing in the coverage of legal affairs. ${ }^{5}$ In addition, several

4. Morton and Sophia Macht Professor of Legal Ethics, University of Maryland; Research Scholar, Institute of Philosophy \& Public Policy.

5. Caplan graduated from Harvard College and Harvard University Law School; he received a grant from the Guggenheim Foundation in 1989-90 to fund the writing of SKADDEN: POWER, MONEY, 
Michigan faculty members agreed to be "internal" guest speakers. While the external speakers tended to have specific, primary interests in legal ethics, the internal speakers tended to be faculty members whose research and teaching areas were in second- and third-year curricular subjects that frequently raise interesting and important ethical questions. Each speaker selected readings to accompany his or her session. Professor Luban delivered several lectures, and I presented the final lecture of the week. In addition to large group lectures, we held several small group discussions, breaking the class into three groups of approximately thirty students each, with various first-year faculty members acting as facilitators.

The wide array of speakers and activities enabled us to achieve many of the abstract objectives I named at the outset of this essay. For example, two internal guest speakers, Professors Debra Livingston ${ }^{6}$ (at that time a member of Michigan's faculty) and Sam Gross, ${ }^{7}$ both of whom teach upperlevel courses, introduced the students to ethical problems in particular areas of legal practice. Professor Livingston, along with Professor Carol Steiker, ${ }^{8}$ discussed the ethical problems endemic to criminal law practice. Professor Gross discussed the relationship between the structure of the American civil system and specific ethical abuses, comparing both the American system and its problems to the German approach and its problems. Both of these speakers illustrated the relationship between legal ethics and other areas of law and the complexities at the intersections; as upperlevel instructors, Professors Livingston and Gross conveyed, through their participation in the bridge week, the important message that a concern with legal ethics must continue throughout law school.

Three speakers from outside the academy demonstrated the practical significance and relevance of legal ethics in three very different contexts. Judge William Schwarzer ${ }^{9}$ discussed the effectiveness of the rules of civil procedure in regulating adversarial excesses. By concentrating specifically on Rules 11 and 26 , Judge Schwarzer confirmed the connection between the first-year curriculum and legal ethics and demonstrated how the nitty-gritty of civil procedure relates to lawyers' ethical conduct.

Like Judge Schwarzer, Harris Weinstein ${ }^{10}$ and Lincoln Caplan provided the students with a conceptual perspective of the world beyond law school. Both spoke about ethical complexities arising in the landscape of corporate practice: Mr. Weinstein discussed the law firm Kaye, Scholer's defense of a rather unsavory corporate client; Mr. Caplan focused on the ethical pressures faced by corporate attorneys, particularly young associates in large firms. Both

\footnotetext{
\& THE RISE OF A LEGAL EMPIRE (1993).

6. Associate Professor of Law, Columbia University.

7. Professor, University of Michigan Law School.

8. Assistant Professor, Harvard University Law School.

9. Senior Judge, U.S. District Court, Northern District of California; Director, Federal Judicial Center, 1990-95; editor, MANUAL FOR COMPLEX LITIGATION (3d ed. 1994).

10. Partner, Covington \& Burling; Chief Counsel, Office of Thrift Supervision, U.S. Dept. of Treasury, 1990-92.
} 
presentations demonstrated the place for sociological and historical study in understanding legal ethics as it arises on the ground. Mr. Caplan, in particular, highlighted this by discussing the history and sociology of corporate law practice in the United States.

Of course, issues of legal ethics are present in areas other than corporate practice and civil and criminal litigation. Thus, we devoted three sessions to exploring legal ethics in non-corporate or non-litigation settings.

Professor William Miller ${ }^{11}$ had previously taught courses in negotiation in which he occasionally discussed related ethical issues. For the bridge week, Professor Miller supervised a negotiation exercise that tempted each side toward ethically questionable conduct to gain a material advantage. Each pair of students conducted the negotiation, and a few pairs' negotiating sessions were videotaped. Professor Miller concluded the exercise by analyzing these taped sessions with the entire group, fielding their questions and comments throughout. In order to simulate the actual conflict of interest, a portion of the students' final grade was based on their performance in the negotiations (the remainder of the grade was based on class participation and performance on a written take-home examination). In other words, as we informed the students in advance, the settlement amounts would be the basis for a grading curve for the negotiation exercise: Students who gained larger settlements on behalf of their clients received higher grades, just as students who spent less money on behalf of their clients also received higher grades. Although many students were alarmed by this zero-sum element of their final grade, we chose to grade the exercise on this basis for several reasons: We wanted the students to experience an authentic clash between the demands of ethics and the demands of material advantage to prompt them to think about the relationship between strategy and ethics; we wanted to heighten the practical relevance of the legal ethics bridge week; and we wanted to evaluate the students' skills other than those elicited by the take-home written examination given at the week's end.

The relationships between negotiations, ethics, and power figured prominently in one of our external guest speaker's presentations. Professor Carrie Menkel-Meadow ${ }^{12}$ showed a videotape of a mock judicial settlement conference and then discussed the ethical positions and behavior of the lawyers and the judge.

Our final guest speaker, Professor Lucie White, ${ }^{13}$ lectured on legal ethics in yet another type of practice-public interest advocacy. We especially wanted the students to see that ethical difficulties do not disappear in the public interest setting. In fact, on the final examination, students were given the option of analyzing one of two ethically complex situations, one drawn from corporate

11. Professor, University of Michigan Law School, who was also teaching the students Property at the time.

12. Professor of Law and Director of the Center for Study of Inter-Racial/Inter-Ethnic Conflict Resolution, U.C.L.A.

13. Professor, Harvard University Law School. 
practice and the other from public interest practice. The class divided about evenly in their selection.

I concluded the bridge week with a lecture entitled "Virtue Ethics and Legal Ethics." In this lecture, I placed the subject of legal ethics in a broader moralphilosophical context, introducing the students to three traditional schools of thought in normative ethics: utilitarianism, Kantianism, and virtue ethics. I aimed to begin to equip the students with a powerful theoretical framework within which to consider legal ethics and, more generally, to demonstrate how ideas and methods of another discipline can aid the legal thinker.

When I prepared the lecture, I hoped that it would motivate me to undertake a more scholarly investigation into its topic, which in fact happened. The lecture became the basis of an article I wrote subsequently. ${ }^{14}$ The research and writing of that article became, in turn, an impetus for developing an upperlevel seminar, designed to investigate the issues and themes of the original lecture more thoroughly and carefully. In the long term, I may create a large-scale upperlevel course based in part on the seminar.

Other Michigan faculty members who have innovated the legal ethics curriculum have experienced an interplay between their teaching and scholarship in this area. Professors Schneider and Syverud have used Keck grant funds to create upperlevel seminars in applied legal ethics. These focused seminars enable students to examine ethical issues in particular areas of legal practice, allowing for a depth of inquiry normally unavailable in the traditional professional responsibility course. Professor Schneider, who has had a longstanding interest in health law, co-taught a seminar in medical ethics with Professor Joel Howell, of the Michigan Medical School and History Department, offered jointly to law students and medical students. Professors Schneider and Howell continue to offer this seminar.

Professor Syverud teamed with Professor Charles Silver of the University of Texas Law School to teach a seminar entitled "Selected Problems in Litigation Ethics." Because Professors Syverud and Silver had prior interests in insurance law, they concentrated on ethical issues confronting the insurance defense lawyer. This emphasis reinforced an important objective of Michigan's innovations: educating students to be alert for often overlooked legal-ethical dimensions of particular practice areas. On the basis of developing and teaching their seminar, Professors Syverud and Silver have produced a scholarly article $^{15}$-another instance of the symbiosis of curricular innovation and faculty research.

14. Heidi Li Feldman, Codes and Virtues: Can Good Lawyers Be Good Ethical Deliberators?, 69 S. CAL. L. REv. 885 (1996).

15. Charles Silver \& Kent Syverud, The Professional Responsibilities of Insurance Defense Lawyers, 45 DUKE L.J. 255 (1995). 


\section{CONCLUSION}

The first-year legal ethics bridge week and the growing number of upperlevel seminars in legal ethics have enabled the Michigan faculty to achieve, or begin to achieve, many of our goals for reformulating the legal ethics curriculum. At least two faculty members-Kent Syverud and myself-who have taught in the ethics bridge weeks have also taught upperlevel seminars. Informally, each of us has begun the process of integrating the lessons of the bridge weeks into upperlevel teaching.

To further coordinate the bridge weeks with upperlevel offerings in legal ethics and to better accomplish both our curricular and scholarly goals in this area, the faculty would like to establish a program on the legal profession, pending faculty development and approval. At the initiative of Dean Lehman, Professor Syverud has begun outlining this enterprise. We anticipate seeking full faculty approval during the 1996-97 academic year.

The program will be designed with considerable participation from faculty members, students, and alumni. The first draft of the proposal contemplates initiatives in four areas: negotiation and dispute resolution; professional responsibility and legal ethics; legal skills; and the study of the legal profession. In addition to promoting curricular innovation, the program will encourage and sponsor faculty scholarship and symposia in these areas. The impetus for such a program comes both from the leading role many of our graduates play in the legal profession and from our commitment to making the sort of ongoing contribution to the profession for which an academic institution is uniquely qualified.

In the area of professional responsibility and legal ethics, the program will continue the legal ethics bridge weeks and upperlevel seminars. But, with additional, long-term financial support and more flexible use of current funding, Michigan's innovations in the legal ethics area should blossom by permitting faculty additional time to refine and elaborate the curricular additions already in place. Moreover, a faculty member or members could be given the time to revamp the upperlevel survey course in professional responsibility, making it an integral part of revitalizing the teaching of legal ethics at Michigan.

More resources with fewer restrictions on their use would also allow faculty and students involved in the professional responsibility and legal ethics part of the program to work in tandem with faculty and students concentrating in other areas (we also expect overlap in the faculty and students working in the different parts of the program). For example, the program on the legal profession could organize and sponsor both courses and scholarly conferences on topics such as the history and sociology of legal ethics in the United States or the economic and moral dimensions of methods of dispute resolution other than litigation. As with the first-year legal ethics week and the upperlevel seminars, the program's courses and conferences will include a large number of 
guest speakers, drawn from other academic disciplines and law schools, and from the practicing bar. Although financing this range of outside speakers is a challenge, it provides the students the excitement of hearing new voices express different perspectives on the issues covered in the legal ethics curriculum.

The University of Michigan Law School has begun to rethink the traditional legal ethics curriculum. Our ambition is to remove all bureaucratic overtones from student coursework in legal ethics. Ultimately, we aim to shift the perception of legal ethics as synonymous with a somewhat tedious professional responsibility requirement to an understanding of legal ethics as an area with tremendous intrinsic merit as well as special relevance to the practice of law. Viewed in this light, studying legal ethics becomes a desirable endeavor rather than a chore to be hastily dispatched. 
